\title{
The Connotation and Implementation Path of Art Education from the Perspective of Aesthetic Education in the New Era
}

\author{
Yanjun $\mathrm{Yu}^{1,2, *} \mathrm{Xia} \mathrm{Jiang}^{3}$ \\ ${ }^{1}$ Xichang Minzu Preschool Normal College, Xichang, Sichuan 615013, China \\ ${ }^{2}$ Center for Studies of Education and Psychology of Ethnic Minorities in Southwest China, Southwest \\ University, Chongqing 400715, China \\ ${ }^{3}$ Music College, Sichuan Normal University, Chengdu, Sichuan 610101, China \\ *Corresponding author.Email:497630478@qq.com
}

\begin{abstract}
A series of documents issued in recent years on strengthening and improving aesthetic education have highlighted the importance and value of the times of aesthetic education and art education. In the context of the new era, it is necessary to deeply understand the connotation of aesthetic education, grasp the relationship between aesthetic education and art education, and explore the essence and characteristics of art education from the perspective of aesthetic education in the new era. To this end, new curriculum goals are given by integrating the concepts of aesthetic education in the new era, taking root in traditional Chinese culture, and digging into artistic connotations, artistic thoughts are analyzed from multiple angles, teaching methods are improved in a diversified manner, and education linkages are integrated in many ways to promote new teaching activities, in order to realize the beauty of educating in art education.
\end{abstract}

Keywords: Art education, Aesthetic education, New era, Implementation path.

\section{INTRODUCTION}

Aesthetic education, as an indispensable part of school education, is of great significance to promote the all-round development of students. Since the 18th National Congress of the Communist Party of China, General Secretary Xi Jinping has given important instructions to the school's aesthetic education. In the report of the 19th National Congress of the Communist Party of China, it was proposed to fully implement the

*Funds: Sichuan Provincial Social Science Planning Project (Popularization Project) "Stomp and Sing in Fields: Sichuan Ethnic Minority Nursery Rhyme" (SC21KP001), project leader: Yanjun Yu. Western Art Project of National Social Science Foundation, "Rescuing Sorting and Research of Sichuan Endangered Folk Song Resources in Tibetan-Qiang-Yi Corridor" (20ED200), project leader: Xia Jiang; Xichang Minzu Preschool Normal College Project, "Investigation on the Localized Teaching Practice of Liangshan Yi Music in Orff's Music Teaching Method" (Xiyou KY201911), project leader: Yanjun $\mathrm{Yu}$; National Folk Music and Dance Research Center, "Research on the Wedding Ceremony Music of the Lisu Nationality in Dechang County, Sichuan Province from the Perspective of Feminism" (MYZC2019-10), project leader: Yanjun Yu; party's education policy, implement the fundamental task of strengthening moral education and cultivating people, develop quality-oriented education, promote educational equity, and cultivate socialist builders and successors with allround ability in areas such as morals, intelligence, physical fitness, work and aesthetics.[1] In particular, the General Office of the State Council issued the "Opinions on Comprehensively Strengthening and Improving School Aesthetic Education" on September 15, 2015. After five years, the General Office of the CPC Central Committee and the General Office of the State Council issued the "Opinions on Comprehensively Strengthening and Improving School Aesthetic Education in the New Era", which pointed out the direction for the reform and development of school aesthetic education in the new era.

"School art education is the most important way and content to implement aesthetic education"[2], and it is the most direct and effective means for aesthetic education to be implemented in schools. 
Strengthening the reform and practice of art education can help to realize the goal of "cultivating people with aesthetic education, influencing people with aesthetic education, and laying the foundation with aesthetic education", and cultivating socialist builders and successors with all-round ability in areas such as morals, intelligence, physical fitness, work and aesthetics. Against the background of the new era, art education should grasp the relationship with aesthetic education, fully regard the guiding ideology and construction requirements of aesthetic education in the new era as the goal guide of art education, and create an art education with aesthetic interest, truth-seeking quality, and a heart towards kindness from the curriculum objectives and teaching organizations, so as to provide a solid and powerful foundation for students to cultivate noble sentiments and shape beautiful minds.

\section{THE RELATIONSHIP BETWEEN AESTHETIC EDUCATION AND ART EDUCATION}

When it comes to the relationship between aesthetic education and art education, it must be inseparable from the analysis of beauty and art. Cai Yuanpei once explicitly said, "Aesthetic education is the application of the theory of aesthetics to education, with the aim of nurturing feelings."[3] Therefore, "To talk about aesthetic education, one must first know about aesthetics."[4] However, in fact, whether one wants to understand the theory of aesthetic education or the theory of art education, one must first understand the meaning of beauty and art.

Are beauty and art equivalent? From a conceptual point of view, beauty is a non-utilitarian and appealing living image that appears in the practice of human symbols.[5] It is an activity that integrates sensibility and reason, part and whole, as well as concept and image.[6] Art is a creative activity in which humans use specific media, forms and methods to express their thoughts and emotions as aesthetic images.[7] It reflects the social ideology of real society and personal emotions, and it is also a manifestation of creative aesthetic spirit. In essence, beauty is to reveal the basic concept and the universal law of "the true, the good and the beautiful"; while art pays more attention to the essence and connotation of "beauty", which is a highly condensed and generalized idea of the sublime and magnificent beauty in things, and is "the perceptual manifestation of ideas".[8] In terms of scope, aesthetics include natural beauty, social beauty, artistic beauty and scientific beauty; while art is one of the objects of aesthetic research, compared to natural beauty and social beauty. In terms of manifestation mode, aesthetics is more focused on theoretical interpretation and construction; while art is a special form that meets people's aesthetics and is usually presented in the form of music, painting, calligraphy, etc. Therefore, it focuses more on the expression and reflection of practice. In terms of chronological order, aesthetic theories are often not synchronized with works of art.[9] For example, sculptures in ancient Greece and totems in ancient times often predate the principles and explanations of aesthetics.

In short, the two are similar in nature, but the content and essence they contain are different. This means that there are also differences between aesthetic education and art education, which are interdisciplinary with education.

Speaking of aesthetic education and art education, from a conceptual point of view, aesthetic education is also called beautyappreciation education, which is a kind of visualized and emotional education that cultivates people according to the standards of beauty. It is the education that usually takes the aesthetic concepts of a specific era and a specific class as the standard, uses image as a means, takes emotion as the core, and aims to achieve the purpose of allround development of human being.[10] Art education is an important part of aesthetic education, which uses artistic methods and contents such as literature, music, and fine arts.[11] It focuses on cultivating appreciation ability, supplemented by creativity, so that educational objects can learn aesthetic knowledge and form aesthetic ability in the practice of appreciating excellent works of art. From the perspective of purpose, the purpose of aesthetic education is broader than art education, which not only includes the cultivation of aesthetic ability, appreciation ability and creativity, but also is an important part of the all-round development of human being. In terms of modes of presentation, aesthetic education includes a variety of practical aesthetics, theoretical aesthetics, and philosophical aesthetic education.[12] It is more philosophical; while art education is more practical. From the perspective of scope, the broad sense of aesthetic education is the emotional education of all things that contain beauty, including landscape aesthetic education, science aesthetic education, etc.; the narrow sense 
of aesthetic education mainly refers to art education.

Therefore, aesthetic education and art education are similar in nature and function. But in school education, "Aesthetic education determines the nature, function, law, and method of art education and becomes the basic orientation of art education."[13] Especially nowadays, aesthetic education often appears in the documents and guidelines of the Party Central Committee and the State Council. The implementation of aesthetic education has become China's state will.[14] How to grasp the connotation and development of art education under the vision of aesthetic education in the new era has become a problem that needs to be solved urgently.

\section{THE CONNOTATION OF ART EDUCATION FROM THE PERSPECTIVE OF AESTHETIC EDUCATION IN THE NEW ERA}

Where is art education under the new era with guidelines of strengthening and improving aesthetic education? To solve this problem, one must first clarify the development course of art education, clarify the policy expression of aesthetic education and art education in the new era, and then deduce the essence of connotation and characteristics of the times of art education from the perspective of aesthetic education in the new era.

\subsection{Historical Origin: the Development Course of Art Education}

Throughout the history of the development of art education, education about the art has arisen from the time when human beings engaged in artistic activities such as music, dance and poetry. In the history of Chinese art education, Da Si Yue in the Western Zhou Dynasty, Music Bureau in the Han Dynasty, Taichang Temple in the Tang Dynasty, imperial music office in the Song Dynasty, etc. were all educational institutions that teach music, dance, and painting for court celebrations in the past dynasties of China. However, during this period, music, painting, dance and poetry were not combined into art education, and there was no special study of art.

The concept of art education was established in Europe in the 18th century. The emergence of this term was related to the rise of the art amateur community. At that time, it was considered that music, dance, and painting were all things for musicians, dancers, and painters, and that they were considered to be the research and learning of one field. Unlike this type of artist, art amateurs went into and out of different art categories and discovered the commonalities of different art categories. Therefore, the term art education gradually came into being.[15] Art education points to the knowledge of non-artists and is a kind of conceptual public education with common characteristics. After the founding of the People's Republic of China, China borrowed from the former Soviet Union and the Western education models, and collectively referred to the education of music, fine arts and other disciplines as art education.

After that, Chinese art education experienced a leapfrog development. The first stage was in the 1980s when the Art Education Committee of the Ministry of Education was established to be responsible for the guidance of colleges and universities and primary and middle schools. This was the revival of art education after the "Cultural Revolution". The second stage was in the 1990s. During this period, the country began to discuss the issue of art education and aesthetic education entering the educational policy. Eventually, during this period, aesthetic education was incorporated into the national education strategy, and the educational policy of "cultivating socialist builders and successors with all-round ability in areas such as morals, intelligence, physical fitness, work and aesthetics" was clearly defined. The third stage was that from the 21 st century, the country gradually began to attach importance to art education. In particular, in 2011, the Academic Degrees Committee of the State Council and the Ministry of Education listed "the study of art" as a separate discipline field, which had more strategic significance for the development of art education. The fourth stage is the important instruction of the Party Central Committee with Comrade Xi Jinping as the general secretary on aesthetic education and art education against the background of the new era. This marks a brand-new period for aesthetic education at all levels and in all types of schools in China.

\subsection{Policy Expression: the Expression of the Connotation of Aesthetic Education and Art Education in the New Era}

Since the 18th National Congress of the Communist Party of China, the Party Central 
Committee with Comrade Xi Jinping as the general secretary has given important instructions on aesthetic education and art education. The Third Plenary Session of the 18th Central Committee of the Communist Party of China clearly proposed "improving the teaching of aesthetics and enhancing students' aesthetic and humanistic qualities". This is the beginning of a new era in which aesthetic education in schools is being taken seriously. In his speech at the symposium on cultural and art work on October 15, 2014, General Secretary Xi Jinping fully affirmed the importance of art work. On November 30, 2016, at the opening ceremony of the Tenth National Congress of the China Federation of Literary and Art Circles and the Ninth National Congress of the Chinese Writers Association, General Secretary Xi Jinping once again emphasized the importance of literary and art work and proposed that "We must attach importance to and strengthen art education to improve the people's artistic accomplishment". His letter in reply to the old professor of the Central Academy of Fine Arts on August 30, 2018 and speech at the National Education Conference on September 10, 2018 made specific requirements for aesthetic education, proposing that "The school's aesthetic education should be comprehensively strengthened and improved and should persist in cultivating people with aesthetic education, influencing people with culture, and improving students' aesthetic and humanistic qualities".[16] Among them, it is worth noting that the two work opinions, the "Opinions on Comprehensively Strengthening and Improving School Aesthetic Education" issued by the General Office of the State Council on September 15, 2015 and the "Opinions on Comprehensively Strengthening and Improving School Aesthetic Education in the New Era" issued by the General Office of the Central Committee and the General Office of the State Council, adhere to the overall goals and construction requirements of aesthetic education in terms of "strengthening moral education and cultivating people" and "cultivating people with aesthetic education". This provides important theoretical guidance for the education goals, nature and practice of aesthetic education and art education in the new era. However, as the country pays more and more attention to and vigorously promotes aesthetic education and art education, there is still a lack of understanding of educational policy and a lag in the objectives and content, theory and practice of aesthetic education and art education in the context of the times in schools.

\subsection{Interpretation of the Times: the Connotation of Art Education from the Perspective of Aesthetic Education in the New Era}

Combining the opinions of school aesthetic education in the new era, art education from the perspective of aesthetic education in the new era is the education that "is under the guidance of $\mathrm{Xi}$ Jinping thought on socialism with Chinese characteristics in a new era, fully implements the party's educational policy, adheres to the socialist orientation in running school, takes 'strengthening moral education and cultivating people' as the foundation, takes the core socialist values as the guide"[17], takes music, dance, art, design, drama and other art categories as the carrier, organically combines artistic theory knowledge, artistic skill training and artistic aesthetic experience, promotes aesthetic accomplishment, enriches imagination and innovative consciousness, and promotes the allround and harmonious development of people. Its main characteristics are:

\subsubsection{Artistic Quality and Humanity}

Artistic quality is the most basic feature of art education. It is to understand and master the performance skills or creative techniques of artistic works through methods such as appreciation, experience, and perception, so as to form an understanding and knowledge of art. The artistic quality of art education includes two aspects: On the one hand, it exists in works with typical images, vivid and tortuous plots, rigorous and complete structures, accurate and distinctive language, and diverse and unique techniques. It is an educational analysis of works with unique artistic characteristics. If one wants to understand the artistic quality of the stage, one must analyze from the aspects of color, light, layout, etc.; to understand the artistic quality of music, it is necessary to analyze the trend of tonal musical form, harmonic musical form, etc. On the other hand, it is a means and method that enables the artistic characteristics of artistic works to be experienced and recognized in the process of education. For example, to appreciate music, one needs to use the method of listening; to sing songs, one needs to use the method of singing. This kind of art education method is an important way to appreciate art and it is a unique way of education that distinguishes it from other disciplines. 
At the same time, art education contains humanity. There are two kinds of humanity. One is derived from the artist's conception and creation of his own life experience in his creation and expression. For example, "Symphony of Destiny" was written by Beethoven when he suffered from ear disease and severe emotional damage in his life and emotions. He once said, "It is art. It is art that keeps me. I must not leave this world until I have completed my mission". It is this spirit of tenacious struggle with destiny that produces magnificent and thrilling music. Therefore, the artistic work condenses the creator's experience and perception of life, which is a manifestation of the humanity of art. The other is derived from the interaction between subject and object in the process of art appreciation, and then the understanding and perception of artistic works are formed. The ancient poem "Grieved o'er the years, flowers make us shed tears; Hating to part, hearing birds breaks our heart" is to project the helplessness and sadness of the ruined country and the starving people into the object, forming a comparison of the image of flowers and birds. This kind of humanity is often accompanied by self-understanding of the work, and it is also an empathetic aesthetic psychological activity.

\subsubsection{Aesthetic Nature and Comprehensiveness}

Aesthetic nature is a unique ideology that is different from humanities, social sciences and natural sciences. It is to guide students to deepen their aesthetic experience through appreciation, experience, perception and creation, so that they can enjoy beauty, cultivate and express their emotions, and then cultivate aesthetic emotions and enhance aesthetic accomplishment. The aesthetic nature of art education is often infectious and nonutilitarian. Just as when appreciating Xu Beihong's "Running Horse", people can break away from the current world and feel a sense of magnificence coming through the clouds and mists and howling in the flying tail hair and the thin and powerful horse legs. They can feel the beautiful scenery of mountains and rivers in the guqin solo "High Mountains" and "Flowing Water" which are "magnificent as Mount Tai" and "flowing as a vast sea".[18] This kind of aesthetics is obtained from the analysis, understanding, experience and perception of works of art such as music and fine arts. It is the study and understanding of the true, the good and the beautiful of human beings.
In addition to aesthetics, art education also includes comprehensiveness. Through the extensive connection with life, culture, technology, etc., through the communication and conversion of vision, hearing, kinesthesia, touch and other senses, comprehensiveness allows students to not only improve their artistic quality, but also increase their exploration of a colorful world. Einstein, who ardently loved the violin, once said: "Research in the fields of music and physics are different in origin, but are linked by a common goal, which is to express the quest for the unknown. Their reactions are different, but they complement each other".[19] Because of this, Einstein's love for music inspired his infinite creativity. Therefore, the comprehensiveness of art education is not the simple addition of knowledge or skills of various art categories, but the generation of new feelings, new ideas, and new forms through the correlation, integration, and dialogue between different categories.

\subsubsection{Intensionality and Creativity}

The intensionality of art education refers to the use of the humanistic characteristics of artistic works to deepen students' in-depth understanding and thinking of art and form an in-depth understanding of things through the exploration and learning of basic artistic works and theories. The profound ideas expressed in artistic works are the most valuable content in art education. These contents are not only related to the shaping of individual values, but also related to the ideological trend of a country and even the world. The "Yellow River Cantata" created by "People's Musician" Xian Xinghai is a song with the Yellow River as a symbol of Chinese national spirit with magnificent and majestic momentum. In art education, teachers fully explore the background of the creation of song, use the Yellow River as a symbol of the Chinese national spirit, and use "roar for the war of resistance" as the content to reveal the heroic spirit of the Chinese nation's tenacious resistance and reflect the invincible power of the Chinese nation. Therefore, art education should be good at using the connotation of artistic works to educate and reflect the value of art in art education.

At the same time, art education is creative. The creativity of art education is to "provide rich educational content and art materials, create open activity scenarios, present challenging learning tasks, and allow students to stimulate their creative potential in various creativity, design, production, 
expression, performance, communication and multi-perspective connection and conversion".[20] The creativity of art education includes: one is innovativeness, and the other is creativity. The difference between the two lies in whether they are based on original objects. Art education grasps the creative characteristics of artistic works and gives full play to the imaginative function of art, so that the society can maintain continuous imagination and creative motivity of the world.

In short, art education under the vision of aesthetic education in the new era is the education that combines artistic quality and humanity, aesthetic nature and comprehensiveness, as well as intensionality and creativity, and aims at cultivating aesthetic accomplishment, cultivating sentiment, warming the soul, enriching imagination and cultivating innovative consciousness.

\section{THE IMPLEMENTATION PATH OF ART EDUCATION FROM THE PERSPECTIVE OF AESTHETIC EDUCATION IN THE NEW ERA}

Under the vision of aesthetic education in the new era, art education must grasp the relationship between beauty and art, and aesthetic education and art education. Especially in the construction of schools, it is necessary to consider the connotation, value and function of aesthetic education, and at the same time reflect the accomplishment of knowledge, skills and emotions of school art education. Therefore, it is necessary to integrate the concepts of aesthetic education in the new era, take root in Chinese traditional culture, and explore artistic connotations as the curriculum goals, analyze artistic thoughts from multiple angles, diversify teaching methods, and organize teaching activities through integrating education linkages in many ways to realize the beauty of educating from the perspective of aesthetic education in the new era.

\subsection{Using Curriculum as a Lighthouse to Guide the Course of Art Education in the New Era of Aesthetic Education}

\subsubsection{Combining the Concept of Aesthetic Education in the New Era to Shape the Beauty of Social Harmony}

"Art is the clarion call for the advancement of the times. It can best represent the style and features of an era and can best lead the ethos of an era".[21] From ancient times to the present, from the "ritual music" in the Western Zhou Dynasty to the "songs of salvation" during the War of Resistance Against Japan, from the establishment of the national anthem to the singing of the classic songs of the centennial of the founding of the party, all reflect this point of view. "The change of the article is affected by the objective situation, and its rise and fall are restricted by the development of the times".[22] Art reflects the style and features of the society of the times, and reflects the law of "existence determines consciousness" in historical materialism. But art is not only a manifestation determining consciousness, it also has initiative. The European Cultural Renaissance Movement, the emergence of Dante, Leonardo da Vinci, and Raphael, the hundred schools of thought in the Spring and Autumn Period and the Warring States Period in China, and the artists emerging during the May Fourth New Culture Movement have greatly promoted social changes. Art not only reflects the social outlook, but also becomes the clarion call for the advancement of the times according to the development of the times, promoting the progress and development of the times.

Under the vision of aesthetic education in the new era, art education should take art as the leader of the times, carry forward the leading role of ideology in art education, and explore artistic works that can demonstrate the beauty of faith and the connotation of sublime beauty. Art is a unique manifestation of human spiritual culture; especially different eras reflect different ideological connotations. Art education must fully grasp its characteristics, grasp the pace of progress of the times, and offer courses that conform to the characteristics of the times and have artistic connotations. At the same time, it is necessary to combine the new concepts and new policies of aesthetic education in the new era to transform the educational purpose of traditional art education of "focusing on cultivating artistic skills and highlighting the perceptual experience of viewers of literary and artistic works",[23] with strengthening moral education and cultivating people as the task and taking "aesthetic accomplishment and humanistic quality" as the course goal, so as to promote the continuous innovation and reformation of art education in the new era, shape the pursuit of a good life as well as the longing and yearning for beauty, and form good social ecological culture. 


\subsubsection{Taking Root in China's Fertile Ground, Promoting the Beauty of Excellent Culture}

"Without a high degree of cultural confidence and cultural prosperity, there would be no great rejuvenation of the Chinese nation".[24] Art is a highly manifestation of spiritual culture, and has the function of transmitting value connotation and leading ideology. As the main carrier of cultural transmission, school art education shoulders the mission of promoting national culture. Under the vision of aesthetic education in the new era, art education must be aware of the significance of education to the transmission of culture, reverse the long-standing misconceptions and practices of "respect for foreignness" and "respect for beauty" in the art education curriculum system,[25] and fully reflect the charm of Chinese excellent culture in the curriculum system.

Chinese traditional culture is the embodiment of national ideology and the soul of the Chinese national spirit. It includes: firstly, the material culture and spiritual culture that have been deposited in China's splendid 5,000-year history; secondly, the socialist ideology that has been preserved in the great struggle, great construction, and development of the party and the people. Therefore, on the one hand, school art education should take it as an important part of the curriculum goals and curriculum content, to understand art, recognize art, and create art from a cultural perspective, forming the artistic spirit and cultural identity. School art education can make full use of traditional Chinese culture, such as traditional Chinese festivals, Chinese historical figures, etc., to guide students to love Chinese culture and then establish patriotism and national pride.

On the other hand, school art education should absorb and transform foreign culture in the process of adhering to the excellent Chinese culture, to form excellent artistic works that conform to the characteristics of socialism and have long-lasting vitality. China's excellent traditional culture itself has been accumulated in the process of continuous cultural fusion. People should not overly reject different cultural thoughts, nor should they overly "follow the foreigners", but should "select the essence and discard the gross", create the national culture with Chinese philosophy, Chinese tolerance, and Chinese charm, and show the beauty of China in "sticking to the standpoint of Chinese culture and inheriting Chinese cultural gene".[26]

\subsubsection{Excavating the Essence of Art, Returning to the Beauty of Educating of Aesthetic Education}

Reflecting on the current situation, art education, which should have been "teaching aesthetics", now often encounter the situation where "aesthetic education is absent". On the one hand, this is because of the alienation of art education. Under the influence of a large number of fueled utilitarian competitions, selections, examinations, etc., parents, students and even art teachers have all rushed in the competitions and selections to improve their artistic performance in order to obtain better "admission tickets".[27] This has turned warm art education into cold mechanical training. On the other hand, there has been a lack of recognition of the educating function of art courses in school education, and "the phenomena of focusing on examinations and neglecting literacy, focusing on the few and neglecting the whole, focusing on competitions and neglecting popularization, muddling through, occupying, and stopping aesthetic education courses" also exist.[28] Some even believe that art education is useless education. One of these two situations is the excessive emphasis on art education, and the other is the indifference to the value function of art education.

Art education is an education that integrates artistic quality and humanity, aesthetic nature and comprehensiveness, and rationality and sensibility, and is also a way of tangible "teaching" to achieve the enrichment and perfection of intangible personality and temperament. Against the background of the new era, art education must first fully explore the connotation of itself, "change the technical and utilitarian tendencies of art learning, and create a healthy and positive social and cultural environment that is conducive to the growth of teenagers".[29] Under the vision of aesthetic education in the new era, the fundamental purpose of art education is "to cultivate people with aesthetic education and to influence people with culture". Its essence is the education of cultivating aesthetics and educating people, and the education of the soul. School art education should change the utilitarian tendency from the conceptual point of view, and let students experience the infiltration of aesthetic perception, the blending of emotions and the collision of hearts from the curriculum. The second is to combine the basic skill training of art with the essence of art. Art skill training is certainly an important way to master and understand art. But 
too much emphasis on skill training often leads to mechanized learning. Art education under the vision of aesthetic education in the new era has humanity and intensionality. Therefore, in the setting of curriculum goals and curriculum content, skill training should be combined with the essence of art. While learning skills, it is necessary to understand and appreciate, and experience and perceive the connotation of art.

In short, as General Secretary $\mathrm{Xi}$ Jinping pointed out in his letter in reply to the old professor of the Central Academy of Fine Arts, art education must "adhere to strengthen moral education and cultivate people, take root in the life of the times, follow the characteristics of aesthetic education, and promote the spirit of Chinese aesthetic education".[30] In the context of the new era, the new fashion of art education should be shaped; under the traditional Chinese culture, it needs to take root in the beauty of art; in the exploration of the essence of art, it should return to the beauty of educating.

\subsection{Using Teaching as a Boat to Achieve the Navigation of Art Education in the New Era of Aesthetic Education}

\subsubsection{Analyzing the Connotation of Art from Multiple Angles, Promoting a Deep Understanding of the Artistic Beauty}

In long-term art teaching, when learning an art course, teachers tend to focus on the learning of knowledge. Whether in school art classes or extracurricular art activities, it often happens that the teacher must talk about colors, lines, proportions, etc. when starting an art class; when starting a music class, the teacher must talk about mode, tonality, harmony and musical form. Of course, understanding art from the theory of art is indeed the way to learn art. However, the school's excessive emphasis on the learning of skills will result in a biased understanding of art.

Suhomlinski once said: "Music education is not about training musicians but training people". The essence of art education is to develop a sense of art form, enrich artistic imagination, and cultivate people who are capable of artistic expression, artistic theory and artistic philosophy. In particular, the cultivation of artistic philosophy is inseparable from the exploration and study of the profound philosophical and humanistic thoughts contained in artistic works. The "Preface to the Poems Collected from the Orchid Pavilion" wrote freely by Wang Xizhi is a kind of humanistic work formed by perceiving the "artistic conception" of the landscape and entrusting the "free spirit", namely, projecting personal emotions into the work. It is a high level condensation of human thought about society and culture. It is with the help of this concrete expression of human cultural thought and philosophical spirit that art education transmits the ideas expressed in works of art in an emotional way. Through understanding and perception, it combines the philosophical value of artistic works with the experience and perception of self-practice to form the purification of the soul and the improvement of the spiritual realm.

Art education in the new era should emphasize the cultural attributes of art and teach students the artistic thoughts of human spiritual and cultural carriers. For example, when teachers teach the symphonic poem cycle "My Motherland", they must not only understand the social experience of composer Smetana, who belongs to the Czech "National Music School", and master the creation background, mode and tonality of the music, but also let students understand the longing for homeland and the praise of hometown contained in "My Motherland". In other words, it is necessary to reveal the cultural connotation of the artistic work based on the analysis of it. As the embodiment of the concentration of human culture and thought, art has the hidden philosophical thought and humanistic connotation. Only by strengthening the deep understanding of the works of art, and strengthening the appreciation and analysis of the works, can it be possible to promote the edification of emotions, the improvement of aesthetics, and the purification of the soul.

\subsubsection{Improving Teaching Methods in a Diversified Manner, Promoting the Experience of Aesthetics and Education in Art Education}

Art education is composed of courses such as music, art, dance, etc. Each course has its own unique and applicable teaching methods. Singing methods are often used in music teaching, and appreciation methods are often used in art teaching... Different subjects have their own unique teaching methods. It is precisely in this way that teachers have become dependent on teaching methods, resulting in excessive use of one or very few teaching methods, which has led to a single 
teaching method and a lack of novelty in teaching organizations. Under the vision of aesthetic education in the new era, art education is a comprehensive education.

Therefore, it is necessary to abandon the simple mechanical application of art education teaching methods. To explore each course, each class has a different teaching method. For example, in the music appreciation class, if the teacher wants students to understand, appreciate, feel, and taste the ideological connotation of art, he should combine the ways of explanation, listening, and expression. At the same time, teaching methods such as Orff's music teaching method and body rhythm can also be used. In other words, teachers should use rich and diverse teaching methods to achieve the improvement of students' artistic accomplishment more efficiently, and realize the aesthetics and education of art education. At the same time, in the teaching process, teachers should also be good at mobilizing various sense organs of the body. Art itself is an artistic image that integrates vision, hearing, and kinesthetics. School art education should well mobilize the role of sense organs, meet the learning needs of students to the greatest extent, stimulate students' enthusiasm for learning, and promote their deep understanding and experience of art and aesthetics.

\subsubsection{Multi-directional Integration of Teaching Linkages to Realize the Artistic Combination of Theory and Practice}

School art education is to present the beauty and art with educational value, aesthetic accomplishment and cultural connotation in society and culture to educators in a concentrated way. "The first function of all works of art is to reproduce interesting phenomena in real life... Art has another function besides reproducing life, which is to explain life". [31] Art is the externalization of all conceptual forms and is the product of the artist's reflection of the consciousness in his mind in a certain social life. In social life, mountains and rivers, sound of the wind, and thunder and lightning are the sources of artistic creation. The artist makes full use of this kind of most basic and richest materials to condense his thoughts in his personal creations. Then, in the understanding of art in education, should art return to the reality? Popular music that is often heard has more audiences than symphonic music that is "too high to be popular "; the lively square dance can arouse people's emotional burst more than the gentle classical dance.

Art education in the new era should make full use of the social function of art. On the one hand, it is necessary to organically integrate the family, society and school, vigorously carry out practice activities of aesthetic education, enrich the content of the activities, and innovate the modes of activities. Schools should be encouraged to carry out home-school cooperation aesthetic education activities with the integration of art theory and art practice, so that students can understand the connotation of artistic works in actual social life, and at the same time condense and create fine art products that are more in line with the characteristics of the times. Efforts should be made to strengthen cooperation with social organizations such as symphony orchestras and choirs and establish the integration of professional art troupes and student art troupes, so as to encourage students not only to love art, but also to understand art better, and then to form an understanding of beauty and art through artistic emotion and professional art learning. On the other hand, it's important to pay attention to the development and utilization of venue resources outside the school. It's needed to organize students to visit and study art troupes by means of visits, inquiry learning, etc., to appreciate art performances and feel the charm of art, make use of cultural centers, libraries, museums and other social resources to fully explore the beauty and artistic elements contained in them, and encourage students to perceive the beauty of nature and society in the social environment and then form a harmonious and social conduct beauty in the school environment, style of study, and style of class.

\section{CONCLUSION}

Although we cannot foresee how art education will develop from the perspective of aesthetic education in the new era, cultivating students' aesthetic and humanistic qualities must be inseparable from school curriculum construction and teaching implementation. This article provides a "should" implementation path for the development of art education from the perspective of aesthetic education in the new era from curriculum construction and teaching links. Regrettably, due to the limited learning, the relationship between aesthetic education and art education cannot be analyzed in depth. It is hoped that future scholars can conduct in-depth analysis 
on this basis and propose a more reasonable and feasible improvement path.

\section{AUTHORS' CONTRIBUTIONS}

This article is written by Yanjun $\mathrm{Yu}$, and $\mathrm{Xia}$ Jiang provides revision guidance.

\section{REFERENCES}

[1] Sun Yong, Fan Guorui. The Statusquo, Problems and Strategies of the Aesthetic Education in Chinese Schools [J]. Educational Science Research, 2018(10):70-75. (in Chinese)

[2] The Ministry of Education of the People's Republic of China (MOE). Several Opinions of the Ministry of Education on Promoting the Development of School Art Education [EB/OL]. (2014-01-14)[2021-0730].http://www.moe.gov. cn/srcsite/A17/moe_794/moe_795/201401/t20 140114_163173.html. (in Chinese)

[3] Editorial Committee of Literary Aesthetics Series. Selected Works of Cai Yuanpei's Aesthetics [M]. Beijing: Peking University Press, 1983:174. (in Chinese)

[4] Chen Wangdao. Collected Works of Chen Wangdao (Volume 1) [M]. Shanghai: Shanghai People's Publishing House, 1979:455. (in Chinese)

[5] Wang Yichuan. Aesthetics and Aesthetic Education [M]. Beijing: Central Radio \& TV University Press, 2007: 30. (in Chinese)

[6] Wang Yichuan. Aesthetics and Aesthetic Education [M]. Beijing: Central Radio \& TV University Press, 2007:14-15. (in Chinese)

[7] Formulated by the Ministry of Education of the People's Republic of China. Standards for General High School Art Curriculum [M]. Beijing: People's Education Press, 2020:1. (in Chinese)

[8] Hegel. Aesthetics (Volume 1) [M]. Beijing: People's Publishing House, 1958:138. (in Chinese)

[9] Qiao Lili. Philosophical Defense Between Art and Beauty $[\mathrm{J}]$. Hundred Schools In Arts, 2020,36(03):25-31+107. (in Chinese)
[10] Gu Jianhua, Zhang Zhanguo, editor-in-chief. Dictionary of Aesthetics and Aesthetic Education [M]. Beijing: The Academy Press, 1999.2:65. (in Chinese)

[11] Gu Mingyuan. Great Dictionary of Education [M]. Shanghai: Shanghai Educational Publishing Press, 1990:163. (in Chinese)

[12] Li Zehou. Four Lectures on Aesthetics [M]. Wuhan: Changjiang Literature Art Press, 2019.7:14. (in Chinese)

[13] Du Wei. On Aesthetic Education and Art Education [J]. Zhejiang Social Sciences, 2000(06):144-148. (in Chinese)

[14] Du Wei. Some Issues on the Understanding of Relationships between Current Aesthetic Education and Art Educationn [J]. Journal of Aesthetic Education, 2019(10):1-6. (in Chinese)

[15] Peng Feng. Four faces of artistic education [J]. Journal of Northeast Normal University (Philosophy and Social Sciences Edition), 2019(05):17-21+2. (in Chinese)

[16] People's Daily Online. Persist in the development path of socialist education with Chinese characteristics, cultivate socialist builders and successors with all-round ability in areas such as morals, intelligence, physical fitness, work and aesthetics [EB/OL]. (20189-11)[2021-07-30]. http://edu.people.com.cn/n1/2018/0911/c1053 -30286253.html. (in Chinese)

[17] The General Office of the Central Committee of the Communist Party of China and the General Office of the State Council issued the Opinions on Comprehensively Strengthening and Improving School Aesthetic Education in the New Era [N]. People's Daily, 2020-1016(004) (in Chinese)

[18] (Song Dynasty) Zhu Changwen. History of Guqin [M]. Compiled by Lin Chen. Beijing: Zhonghua Book Company, 2010: 30. (in Chinese)

[19] Compiled by Xu Liangying et al. Collected Works of Einstein: An Enlarged Edition. Volume 1 [M]. Beijing: The Commercial Press, 2009:410. (in Chinese)

[20] Ministry of Education of the People's Republic of China. Art Curriculum Standards 
for Compulsory Education (2011 Edition) [M]. Beijing: Beijing Normal University Press, 2012: 2. (in Chinese)

[21] Xinhuanet. Xi Jinping: Speech at the Symposium on Cultural and art work [EB/OL]. (2015-10-14) [2021-07-30]. http://www.xinhuanet.com/politics/201510/14/c_1116825558.htm. (in Chinese)

[22] Liu Xie. Wen Xin Diao Long [M]. Translated and annotated by Wang Zhibin. Beijing: Zhonghua Book Company, 2021.6:511. (in Chinese)

[23] Zeng Tianyi, Li Yan. Discourse Construction of Art Education in the New Era [J]. Journal of Sichuan University of Science \& Engineering (Social Science Edition), 2020,35(05):88-100. (in Chinese)

[24] Xi Jinping. Secure a decisive victory in building a moderately prosperous society in all respects, win the great victory of socialism with Chinese characteristics in the new era [M]. Beijing: People's Publishing House, 2017:40. (in Chinese)

[25] Guo Shengjian, Liu Shan. Basic Points Followed for School Art Education in New Era $[\mathrm{J}]$. Journal of Aesthetic Education, 2019(04):19-25. (in Chinese)

[26] Commentator of the newspaper. Adhere to the standpoint of Chinese culture and inherit Chinese cultural gene $[\mathrm{N}]$. Journal of Literature and Art, 2017-02-08(001). (in Chinese)

[27] Guo Shengjian, Deng Xi. Returning Arts Education to the Essence of Aesthetic-based Education $[\mathrm{J}]$. Kecheng. Jiaocai. Jiaofa. 2019,39(10):90-97. (in Chinese)

[28] Central People's Government of the People's Republic of China. The State Council's Opinions on Comprehensively Strengthening and Improving School Aesthetic Education [EB/OL]. (2015-09-15) [2021-07-30]. http://www.gov .cn/zhengce/content/201509/28/content_10196.htm. (in Chinese)

[29] Central People's Government of the People's Republic of China. The State Council's Opinions on Comprehensively Strengthening and Improving School Aesthetic Education [EB/OL]. (2015-09-15) [2021-07-30]. http://www.gov .cn/zhengce/content/201509/28/content_10196.htm. (in Chinese)

[30] Xinhuanet. Xi Jinping: Do a good job in aesthetic education, promote the spirit of Chinese aesthetic education [EB/OL]. (201808-30) [2021-07-30]. http://www.xinhuanet.com/politics/leaders/ 2018-08/30/c_1123355775.htm. (in Chinese)

[31] (Russia) Chernyshevsky. The aesthetic relationship between art and reality [M]. Beijing: People's Literature Publishing House, 1957:94-95. (in Chinese) 